\title{
Phytochemical Composition and Antifungal properties of Leaf, Stem and Florets of Panicum maximum Jacq. (Poaceae)
}

\author{
U. C. Kanife (Corresponding author) \\ Department of Biological Sciences, Yaba College of Technology \\ P. M. B 2011, Yaba Lagos, Nigeria \\ Tel: 234-806-065-3964 E-mail: claribeb_ife@yahoo.com \\ O. S. Odesanmi \\ Department of Biochemistry, College of Medicine \\ University of Lagos, Nigeria \\ Tel: 234-803-346-6861Ｅ-mail: loladot.2001@yahoo.com \\ V. F. Doherty \\ Department of Biological Sciences, Yaba College of Technology \\ P. M. B 2011, Yaba Lagos, Nigeria \\ Tel: 234-803-310-7074 E-mail: fumilayodoherty@yahoo.com
}

$\begin{array}{lc}\text { Received: February 11, } 2012 & \text { Accepted: February 25, } 2012 \quad \text { Published: April 1, } 2012 \\ \text { doi:10.5539/ijb.v4n2p64 } & \text { URL: http://dx.doi.org/10.5539/ijb.v4n2p64 }\end{array}$

\begin{abstract}
Ethanol extracts of leaf, stem and florets of Panicum maximum plant were investigated for antifungal activity by disc diffusion agar method. The phytochemical composition of the extracts were also determined. Leaf and floret extracts had significant antifungal activity with varing zones of inhibition on Aspergillus tamari, Aspergillus fumigatus, Aspergillus niger and Candida albican: isolated from patients with skin diseases. The ethanol leaf extracts was more active than the floret extract. The ethanol leaf extract of Panicum maximum caused highest zone of inhibition $(15.0 \pm 0.1 \mathrm{~mm})$ on A. tamari. The three extracts contain alkaloids, tannins, saponins and flavonoids in varying quantities which may have been responsible for the variation in their activities. Results support the use of this plant as antifungal agent.
\end{abstract}

Keywords: Antifungal activity, Alkaloids, Tannins, Saponins, Panicum maximum

\section{Introduction}

Antimicrobials of plant origin have enormous therapeutic potential and have been used since time immemorial. They have proved effective in the treatment of infectious diseases, simultaneously mitigating many of the side effects which are often associated with synthetic antibiotics. Positive response of plant based drugs might lie on the structure of the natural products which reacts with toxins and/pathogens in such a way that less harm is done to other important molecules or physiology of the host (Sharma and Kumar, 2009). Researchers are increasingly turning their attention to natural products looking for new leads to develop better drugs against cancer, as well as oral and microbial infections (Hoffmann et al., 1993, Srinivasan et al., 2001). According to World Health Organization (WHO), more than $80 \%$ of the world's population relies on traditional medicines for their primary health care needs. The medicinal value of plants lies in some chemical substances that produce definite physiological action on human body. The most important of these bioactive compounds of plants include alkaloids, flavonoids tannins and saponins. The phytochemical research based on ethno-pharmacological information is generally considered an effective approach in the discovery of new anti-infective agents from higher plants (Duraipandiyan, Ayyanar and Ignacimuthu, 2006). 
Panicum maximum Jacq. (Poaceae) commonly known as guinea grass and "Iran nkun" in Yoruba is indigenous to Africa and distributed in tropics and subtropics (Aganga and Tshwenyane, 2004). It is a tufted, perennial grass often with a shortly creeping rhizome, variable $60-200 \mathrm{~cm}$ high, and leaf blades up to $35 \mathrm{~mm}$ wide tapering to fine point. The higher essence is a panicle of spikelet up to $70 \mathrm{~cm}$ long and each spikelet consists of 1.5 florets with bracts. The flower is bisexual with 3-4 stamens and brown anthers. (Gibbs et al., 1991; Dutta, 2000; Reinheimer et al., 2005; Doss et al., 2011). Doss et al., (2011) reported antibacterial activity of $P$. maximum leaf on selected bacterial strains when compared with the standard drug - ciprofloxacin. It has also been shown to be antidiabetic and thus can be used for treating diabetic cases and diseases caused by some pathogenic bacteria. However, there has been no report on antifungal properties of the leaf, stem and floret of this commonly grown grass. This research paper therefore sets out to investigate report the antifungal properties of the leaf, stem and floret of $P$. maximum and phytochemical components of these parts of the plant.

\section{Materials and Methods}

\subsection{Collection and identification of plant parts}

Fresh plant parts (leaf, stem and floret) were collected from Ikorodu, Lagos in 2010. They were identified, authenticated by Professor Olowokudejo and deposited in Lagos University Herbarium (LUH 3687). The plant parts were cleaned, dried at room temperature at about $28-30^{\circ} \mathrm{C}$ for one week, after which the parts were grinded into powder form separately and weighed.

\subsection{Extraction technique}

About 400g of each of the Panicum maximum plant parts (leaf, stem and floret) were soaked separately in $200 \mathrm{mls}$ of $95 \%$ ethanol for 72 hours, on separate flasks. Extracts were obtained and dried with rotatory evaporator at reduced temperature $\left(40^{\circ} \mathrm{C}\right)$ and pressure. The extracts were washed free of ethanol and then redried. The dry extracts were stored in refrigerator at $4{ }^{\circ} \mathrm{C}$ in sterile bottles until used.

\subsection{Preparation of culture media}

All culture media were prepared according to manufacturers' instruction and autoclaved at $121^{\circ} \mathrm{C}$ for $15 \mathrm{mins}$.

\subsection{Preparation of microorganisms used}

The test organisms, Aspergillus tamari, Aspergillus fumigatus, A. flavus and Candida albicans were collected from the National Institute of Medical Research, Yaba Lagos, Nigeria (NIMR). All the fungi were cultured using sabuaroid dextrose agar. Serial dilution was carried out the isolates and $10^{-6}$ of the serial dilution was used for the sensitivity test

\subsection{Reconstitution of extract}

The dried extracts were reconstituted by dissolving $50 \mathrm{mg}, 100 \mathrm{mg}$ and $150 \mathrm{mg}$ in $3 \mathrm{ml}$ of sterile distilled water respectively. The solutions were filtered into separate sterile conical flasks. The stock solutions were sterilized by filtration through filter paper to remove impurities and contaminants. The stock solution was further dissolved at different concentration and it was then stored in sterile universal bottles and refrigerated for further analysis.

\subsection{Antifungal screening for reconstituted extracts}

Disc diffusion method according to Irobi and Daramola, (1994) was used. Locally prepared paper discs of 6mm diameter were prepared using a whatman NO.1 filter paper. Hundred discs were sterilized in an oven at $150^{\circ} \mathrm{C}$ for $15 \mathrm{~min}$. The discs were impregnated with different concentrations of crude extracts (leaf, stem and florets). The discs were evaporated at $37^{\circ} \mathrm{C}$ for $24 \mathrm{~h}$. Prepared discs containing the various fractions were carefully placed on the inoculated plates using sterilized forceps in each case. The disc soaked in water served as negative control while disc with ketoconazole (standard) was used as positive control. The plates were then turned upside -down and incubated at $37^{\circ} \mathrm{C}$ for $24 \mathrm{~h}$ in an incubator. The results were taken by considering the zone of growth and inhibition of the organisms by the test fractions. Antifungal activity was evaluated by measuring the diameter of the inhibition zone (z) around the disc. The assay was repeated thrice and mean was calculated.

The zone of inhibition was calculated by measuring minimum dimension of the zone of no fungal growth around the filter paper disc.

\subsection{Phytochemical screening}

Chemical tests were carried out on the ethanol extracts using standard procedure to identify the constituents as described by Sofowora (1993), Trease and Evans (1985) and Harborne (1973). 


\subsubsection{Qualitative analysis of plant parts constituents}

2.7.2 Test for flavonoids: About $5 \mathrm{ml}$ of $10 \%$ dilute ammonia solution was added to a portion of the aqueous literate of the plant extracts, followed by addition of concentrated $\mathrm{H}_{2} \mathrm{~S}_{4}$. A yellow coloration observed in the extract indicated the presence of flavonoid.

2.7.3 Test for saponins: About $2 \mathrm{~g}$ of the powdered sample was boiled in $20 \mathrm{ml}$ of distilled water in a water bath and filtered. $10 \mathrm{ml}$ of the filtrate was mixed with $5 \mathrm{ml}$ distilled water and shaken vigorously for stable persistent froth. The frothing was mixed with 3 drops of olive oil, shaken vigorously for uniformly and was then observed for the formation of emulsion.

2.7.4 Test for tannins: About $0.5 \mathrm{~g}$ of the dried powdered sample was boiled in $20 \mathrm{ml}$ of water in a test tube and then filtered. A few drops of $0.1 \%$ ferric chloride was added and observed for brownish green to a blue-black coloration. Presence of brownish green or blue-black colouration conformed the presence of tannins.

2.7.5 Test for Cardiac Glycosides: About $5 \mathrm{ml}$ of the extracts were treated with $2 \mathrm{ml}$ of glacial acetic acid containing 1 drop of ferric chloride solution $(0.1 \%)$. This was under large with $1 \mathrm{ml}$ of concentrated $\mathrm{H}_{2} \mathrm{So}_{4}$. A browning of the interface suggest a deoxylsugar characteristic of cardenolodes A violet ring may appear while in the acetic layer, a greenish ring may form gradually.

2.7.6 Test for phlobatannin: An aqueous extract of the plant sample was boiled with $1 \%$ aqeous hydrochloric acid and deposition of red precipitate was taken as evidence for the presence of phlobatannins.

2.7.7 Test for Terpenoids: About $5 \mathrm{ml}$ of each extract was mixed in $2 \mathrm{ml}$ chloroform, and concentrated $\mathrm{H}_{2} \mathrm{SO}_{4}(3 \mathrm{ml})$ was carefully added for form a layer. A reddish brown coloration of the interface was formed to suggest positive results for the presence of terpenoids.

2.7.8 Test for steroids: About $2 \mathrm{ml}$ of acetic anhydride was added to $0.5 \mathrm{~g}$ ethanol extract of each of the sample with $2 \mathrm{ml} \mathrm{H}_{2} 50_{4}$. The color changed from violet to blue or green indicating the presence of steroids.

\subsubsection{Quantitative analysis of plant parts constituents}

2.7.10 Alkaloid determination using harborne (1973) method was used. Dry plant parts sample of 5g was weighed into a $250 \mathrm{ml}$ beaker and $200 \mathrm{ml}$ of $10 \%$ acetic acid in ethanol was added, covered and allowed to stand for 4 hours. This was filtered and the extract was concentrated on a water bath to one quarter of the original volume. Concentrated ammonium hydroxide was added drop wise to the extract until the precipitation was complete. The whole solution was allowed to settle and the precipitate was collected and washed with dilute ammonium hydroxide and then filtered. The residue is the alkaloid, which was dried and weighed.

2.7.11 Tannin determination by Van-burden and Robinson (1981) 500mg of the sample was weighed into a 50ml and shaken for 1 hour in a mechanical shaker. This was filtered into a $50 \mathrm{ml}$ volumetric flask and made up to the mark. Then $5 \mathrm{ml}$ of the filterate was pipetted out into a test tube and mixed with $2 \mathrm{ml}$ of $0.1 \mathrm{M} \mathrm{FeCl}_{3}$ in $0.1 \mathrm{M} \mathrm{HC1}$ and $0.008 \mathrm{~m}$ potassium Ferrocyanide. The absorbance was measured at $120 \mathrm{~nm}$ within $10 \mathrm{~min}$.

\subsubsection{Saponin determination: The method used was that of Obadoni and Ochuko (2001).}

The samples were ground and $20 \mathrm{~g}$ of each were put into a conical flask and $100 \mathrm{~cm}^{3}$ of $20 \%$ aqueous ethanol were added. The samples were heated over a hot water bath for 4 hours with continuous stirring at about $55^{\circ} \mathrm{C}$. The mixture was filtered and the residue re-extracted with another $200 \mathrm{ml} 20 \%$ ethanol. The combined extract was reduced to $40 \mathrm{ml}$ over water bath at about $90^{\circ} \mathrm{C}$. The concentrate was transferred into a $250 \mathrm{ml}$ separatory funnel and $20 \mathrm{ml}$ of diethyl ether was added and shaken vigorously. The aqueous layer was recovered while the ether layer was discarded. The purification process was repeated. $60 \mathrm{ml}$ of n-butanol was added. The combined n-butanol extracts were washed twice with $10 \mathrm{ml}$ of $55 \%$ aqueous sodium chloride. The remaining solution was heated in a water bath. After evaporation the samples were dried in the oven to constant weight, the saponin content was calculated as percentage.

2.7.13 Flavonoid determination by the method of Boham and Kocipaiabyazan (1974) $10 \mathrm{~g}$ of the plant sample was extracted repeatedly with $100 \mathrm{ml}$ of $80 \%$ aqueous methanol at room temperature. The whole solution was filtered through Whatman filter paper No. $42(125 \mathrm{~mm})$. The filtrate was later transferred into a crucible and evaporates into dryness over water both and weighed to a constant weight.

\section{Result}

The results of the antifungal screening of the crude extracts of leaf, stem and floret of Panicum maximum plant is presented in Table 1. The leaf and floret extracts showed significant antifungal activity on most of the fungi tested while the stem extract did not inhibit the test organisms. The leaf extract caused a significant increase in 
growth inhibition of Aspergillus tamari, A.fumigatus and A. niger as the concentration of the extract increased while the floret extract inhibited the growth of all the organisms tested. However, ethanol leaf extract of $P$. maximum was the most active with $15.0 \pm 0.1 \mathrm{~mm}$ zone of inhibition on Aspergillus tamari. The stem extract did not cause any growth inhibition of all the fungal organisms tested. The antibiotic, ketocanozole had a significant higher zone of inhibition when compared with water (negative control) and the three extracts. It produced largest inhibition against Candida albican $(25.1 \mathrm{~mm})$. The fungi responded to increase in concentration gradient for the antifungal active extracts. Thus, zones of inhibition in the fungi increased as the concentration of the leaf and floret extracts increased. The leaf and florets contains alkaloids, tannins, saponins and flavonoids in varying percentages. The leaf contains more alkaloids and saponins than the floret and stem extracts. (Table 2 and 3 ).

\section{Discussion}

The significant antifungal action of ethanol leaf and floret extracts of $P$. maximum suggests the presence of potent antifungal components. Adekunle et al., (2005) obtained similar results on Ficus vallis - choudae and Detarium microcarpum. Variation in zones of inhibition of growth of test organisms caused by the two extracts suggests host specificity of the extracts (Adekunle and Okoli, 2002). The presence of biologically active constituents such as alkaloids, tannins, saponins and flavonoids in leaf and florets though in varying percentages might be responsible for the antifungal activity observed in the present study. Also the potency of leaf extract when compared with stem and floret could be due to high percentage of alkaloids and saponins in the extract. Alkaloids have been reported to posses antimicrobial activity against organisms such as klebsiella pueumonia and Candida albican (Addae - Mensah, 1992). Inhibition of cell wall formation resulting in death of fungi was attributed to tannins in Terminalia citrina extracts (Burapadja and Bunchoo, 1995).

However, non- inhibition of Candida albican and Aspergillus flavus suggests resistance of these fungi to the active component present in the leaf extract.

Tannins can also act as antifungal agent by coagulating the protoplasm of the microorganism as reported by Onolapo and Owonubi (1993). Biological function of flavonoids includes protection against allergies, inflammation, free-radicals, platelet aggregation, microbes, ulcer, hetatoxins and tumors (Okwu, 2004). This may have contributed to its activity on test organisms. Adekunle et al., 2005 also reported flavonoids to be responsible for anti fungal activity of some other medicinal plants. The absence of alkaloids, tannins and saponins in the stem extract may be responsible for its non-activity against all the organisms tested.

\section{Conclusion}

It could be concluded from these study that the leaf and floret extract of $P$. maximum showed antifungal activity against the tested isolates and thus suggests their components as promising for development for antibiotics for treating diseases caused by the fungal isolates. However, it is important that these extracts especially the leaf and floret extracts be further purified through bioassay- guided fractionation to isolate the active constituent.

\section{References}

Adekunle A. A., \& Okoli, S. O. (2002). Antifungal activity of the Crude Extract of Alafia bateri Oliver (Apocynaceae) and Hasmanthera dependens Hochst. (Menispermaceae). Hamdard Medicus, 55(3), 52-56.

Adekunle, A. A., Familoni, O. B., \& Okoli, S. O. (2005). Antifungal activity of Bark Extract of Ficus Vallis Choudae Delite - boll (Moraceae) and Detarium Microcarpum Guill-Perr. Caesalpinaceae. Journal of Life \& Physical Sciences, 2(2), 64-67

Aganga, A. A., \& Tshwenyane, S. (2004). Potentials of Guinea grass (Panicum maximum) as forage crop in livestock production. Pakistan Journal of Nutrition, 3(1), 1 - 4. http://dx.doi.org/10.3923/pjn.2004.1.4

Burapadja, S., \& Bunchoo, A. (1995). Antimicrobial activity of Tannins from Terminalia Citrina. Planta Medica, 61(3), 365-366. http://dx.doi.org/10.1055/s-2006-958103

Doss, A., Parivuguna, V., Vijayasanthi, M., \& Surendran, S. (2011). Antibacterial evaluation and Phytochemical analysis of certain medicinal plants. Journal of research in Biology, 1, 24-29

Duraipandiyan, V., Ayyanar, M., \& Ignacemuthu, S. (2006). Antimicrobial Activity of Ethnomedicinal Plants used by Palyar Tribe from Tamil Nadu India. Complementary Alternative Medicine, 635.

Dutta, A. C. (2000). Botany for Degree Students. (6thed.) McGraw Publishers New York. pp. 710.

Gibbs, G. E., Watson, L., Koe Kemoer, M., Smook, L., Barker, N. P., Anderson, H. M., \& Dallwitzx, M. J. (1991). Grasses of Southern African. Memoirs of Botanical Survey of South Africa, 58, 10 - 11.

Harborne, J. B. (1973). Phytochemcial Methods. Chapman and Hall Ltd, London. pp. 378. 
Hoffmann, J. J. N., Timmerman, r. Mclaughlin, \& Punnapayak, H. (1993). Potential antimicrobial activity of Plants from the South Western United States. Int. J. Pharmacology, 31, 101-115.

Irobi, O. N., \& Daramola, S. O. (1994). Antifungal activities of crude extracts of Mitracarpus villosus (Rubiaceae). Journal Ethnopharmocol, 4, 604-610.

Obdoni, B. O., \& Ochuko, P. O. (2001). Phytochemical studies and comparative efficacy of the crude extract of homostatic plants in Edo and Delta States of Nigeria. Global Journal of Prime Applied Science, 86, 203 - 208.

Okwu, D. E. (2005). Phytochemical vitamins and mineral contents of two Nigeria Medicinal Plants. International Journal of Molecular Medicine and Advance Science, 4, 375-381.

Onadapo, J. A., \& Owonubi, N. O. (1993). The antimicrobial Properties of Trenia Gluneensis: In: $1^{\text {st }}$ NAAP Proceedings Faculty of Pharmaceutical Science, ABU Zaria, 139-144.

Reinheimer, R., Pozener, R., \& Vegette, A. C. (2005). Inflorescence, spikelet, and floret of Panicum maximum and Drochloa plantaginea (poaceae). American Journal of Botany, 92, $565 \quad-\quad 575$. http://dx.doi.org/10.3732/ajb.92.4.565

Sharma, B., \& kumar P. (2009). Extraction and Pharcological Evaluation of some extracts of Tridax Procumbens and Capparis Cecolna. International Journal of Applied Research in National Products, 1(4), 5 -12.

Sofowora, A. (1993). Medicinal Plants and Traditional Medicine in Africa. Spectrum Books Ltd, Ibadan, 289.

Srinivasan, D., Nathan, S., Suresh, T., \& Penumalsamy, P. L. (2001). Antimicrobial activity of certain Indian Medicinal Plants used in Folkloric Medicine. J. Ethnopharmacology, 74, $217-220$. http://dx.doi.org/10.1016/S0378-8741(00)00345-7

Trease, S. E., \& Evans, W. C. (1985). Pharmacognosy (13 ${ }^{\text {th }}$ ed.) Bailliere Tindall, England, 832.

Van-Burden, T. P., \& Robinson, W. C. (1981). Formation of complexes between protein and tannin acid. J. Agric Food Chem., 1, 77-86.

Table 1. Antifungal activity of ethanol extracts of leaf, stem, and florets of Panicum maximum plant Zones of inhibition (Mean \pm sem $\mathrm{mm}$ )

\begin{tabular}{|c|c|c|c|c|c|}
\hline Extracts & $\begin{array}{c}\text { Aspergillus } \\
\text { tamari }\end{array}$ & $\begin{array}{l}\text { Aspergillus } \\
\text { fumigatus }\end{array}$ & $\begin{array}{l}\text { Asperagillus } \\
\text { flavus }\end{array}$ & $\begin{array}{c}\text { Aspergillus } \\
\text { nigers }\end{array}$ & Candida albican \\
\hline control (water) $(5 \mathrm{ml})$ & $0.0 \pm 0.0$ & $0.0 \pm 0.0$ & $0.0 \pm 0.0$ & $0.0 \pm 0.0$ & $0.0 \pm 0.0$ \\
\hline Keto conazole (100mg.ml) & $16.1 \pm 0.3$ & $17.1 \pm 0.8$ & $16.0 \pm 0.0$ & $13.0 \pm 0.3$ & $20.0 \pm 0.8$ \\
\hline \multicolumn{6}{|l|}{ Leaf Extracts (mg/ml) } \\
\hline 50 & $6.0 \pm 0.0$ & $10.0 \pm 0.1$ & $6.0 \pm 0.0$ & $7.0 \pm 0.2$ & $0.0 \pm 0.0$ \\
\hline 100 & $12.0 \pm 1.0$ & $11.0 \pm 0.3$ & $0.0 \pm 0.0$ & $9.0 \pm 0.1$ & $0.0 \pm 0.0$ \\
\hline 150 & $15.0 \pm 0.1$ & $13.2 \pm 0.4$ & $0.0 \pm 0.0$ & $12.0 \pm 0.8$ & $0.0 \pm 0.0$ \\
\hline control(water) (5ml) & $0.0 \pm 0.0$ & $0.0 \pm 0.0$ & $0.0 \pm 0.0$ & $0.0 \pm 0.0$ & $0.0 \pm 0.0$ \\
\hline Ketoconazole (100mg.ml) & $20.0 \pm 0.4$ & $15.0 \pm 1.0$ & $15.0 \pm 0.8$ & $17.0 \pm 0.8$ & $16.0 \pm 0.0$ \\
\hline \multicolumn{6}{|l|}{ Stem Extract $(\mathrm{mg} / \mathrm{ml})$} \\
\hline 50 & $0.0 \pm 0.0$ & $0.0 \pm 0.0$ & $0.0 \pm 0.0$ & $0.0 \pm 0.0$ & $0.0 \pm 0.0$ \\
\hline 100 & $0.0 \pm 0.0$ & $0.0 \pm 0.0$ & $0.0 \pm 0.0$ & $0.0 \pm 0.0$ & $0.0 \pm 0.0$ \\
\hline 150 & $0.0 \pm 0.0$ & $0.0 \pm 0.0$ & $0.0 \pm 0.0$ & $0.0 \pm 0.0$ & $0.0 \pm 0.0$ \\
\hline control(water) $(5 \mathrm{ml})$ & $0.0 \pm 0.0$ & $0.0 \pm 0.0$ & $0.0 \pm 0.0$ & $0.0 \pm 0.0$ & $0.0 \pm 0.0$ \\
\hline Ketoconazole $(100 \mathrm{mg} / \mathrm{ml})$ & $17.5 \pm 0.3$ & $18.5 \pm 1.2$ & $14.0 \pm 0.2$ & $16.0 \pm 1.0$ & $25.0 \pm 0.8$ \\
\hline Floret extract 50 & $7.1 \pm 0.2$ & $6.0 \pm 0.1$ & $9.0 \pm 0.3$ & $8.0 \pm 0.1$ & $8.0 \pm 0.1$ \\
\hline 100 & $8.8 \pm 0.1$ & $6.2 \pm 0.0$ & $10.0 \pm 0.8$ & $10.0 \pm 0.3$ & $8.8 \pm 0.3$ \\
\hline 150 & $12.0 \pm 1.0$ & $11.7 \pm 0.2$ & $12.0 \pm 0.2$ & $14.0 \pm 0.0$ & $12.1 \pm 1.4$ \\
\hline
\end{tabular}


Table 2. Phytochemical components present in leaf, stem and floret of Panicum maximum plant

\begin{tabular}{|l|c|c|c|}
\hline Phytochemical components & Leaf & Stem & Floret \\
\hline Alkaloids & + & - & + \\
\hline Tannins & + & - & + \\
\hline Saponins & + & - & + \\
\hline Flavonoids & + & + & + \\
\hline Steroids & - & - & - \\
\hline Phlobatanins & - & - & - \\
\hline Cardiac glycosides & - & - & - \\
\hline Terpenoids & - & - & - \\
\hline
\end{tabular}

Table 3. Percentage composition of active ingredients in leaf, stem and florets of Panicum maximum plant

\begin{tabular}{|l|c|c|c|}
\hline Phytochemical components & Leaf (\%) & Stem (\%) & Floret (\%) \\
\hline Alkaloids & 2.83 & 0.0 & 0.31 \\
\hline Tannins & 0.85 & 0.0 & 0.09 \\
\hline Flavonoids & 0.54 & 0.34 & 0.78 \\
\hline Saponins & 2.60 & 0.0 & 1.83 \\
\hline
\end{tabular}

